\title{
Empirical Analysis of Establishing an Intrinsic Value Evaluation Model of Listed Companies Based on Multivariate Linear Regression Method
}

\author{
Jiaxin Wang ${ }^{1}$,Yanxia Wang ${ }^{2}$ and Donglin Wang ${ }^{1}$ \\ ${ }^{1}$ Department of Basic Education, Beijing Polytechnic, Beijing, China \\ ${ }^{2}$ Telecom Engineering College, Beijing Polytechnic, Beijing, China
}

\begin{abstract}
Enterprise value assessment is a hotspot of research on modern financial problems; profound changes have taken place in China's stock market system and investment environment, in the direction of more fair, effective and standardized development, Chinese stock market is more and more showing the intrinsic investment value. On the basis of the value evaluation model of the mainstream asset appraisal method in the stock market, combining the profitability of the stock, the growth and the domestic current situation of the stock market, this article builds the suitable mathematical model for the evaluation of the intrinsic value of listed companies of China stock market, and selects the empirical model effect on listed companies in the Shanghai market. Through empirical analysis, it is found that: in this paper, the evaluation results from the construction of mathematical model of the intrinsic value of Shanghai a-share listed companies are in accordance with the reality, and are of certain rationality. At the same time, it is also found that the evaluation results of blue-chip shares with the model of correlation degree is higher, and the evaluation results of new shares and small-cap stocks in correlation with its share price a bit weak. This may be related to new shares and small-cap stocks in the full-bodied market hype atmosphere and share price volatility.
\end{abstract}

Keywords-value investing; intrinsic value evaluation model; listed company

\section{INTRODUCTION}

With the rapid and sustained development of China economy, global participation gradually deepened, Chinese stock market has been greatly developed since 1988, while the number of the listing Corporation has also increased from initially 14 to more than 2000 now, expanded by nearly 150 times. With the reform of the securities market as well as other reforms in China, the securities market has been increasingly standardized and improved, in which investment value gradually replace the irrational speculation to become the mainstream investment philosophy of the market. At the beginning of 2008, with the global financial crisis, the stock market has been hit hard, and the majority of investors believe in the value of investment ideas also suffered from heavy losses. Thus the value investment philosophy has been questioned, even many experts and scholars have questioned the value of the investment philosophy, believing that the concept is not suitable for China market, and have written a number of articles to support this point of view.
Research significance of this paper is to adhere to the service for small and medium-sized investors, on the basis of the mainstream value evaluation model on the market, combining the domestic current situation of the stock market, based on the new accounting standards, to build an intrinsic value evaluation model of listed companies suitable for China's stock market, which has comprehensive evaluation of the investment value of listed companies, and finally concluded investment advice. This will help the investors to build up the idea of value investment, master the methods of evaluation enterprise intrinsic value, and reduce the speculation on the market, development of rational investment; To regulate the order of the stock market in China at the same time, promoting the healthy development of stock market can play a positive role.

\section{TO CONSTRUCT CHINA'S STOCK MARKET VALUE EVALUATION MODEL}

\section{A. Quantitative Analysis of the Intrinsic Value of Listed Companies}

1. The calculation of the net value of each asset of the listing Corporation

The book value of the listed company is listed on the balance sheet of the data values, but due to the different companies in the industry competitive position is different, plus depreciation and amortization, book value cannot really reflect the company's assets value. And reset the value of the asset is through the reset method to adjust the book value, truthfully reflect the value of the asset of the company.

The calculation formula is as follows:

Company reset value $=$ Reset total assets - Reset liability

Net asset value per share $(B V)=$ Owners' equity in total after the adjustment value/ Total share capital=(Reset total assets Reset liability) / Total share capital

2. The calculation of the listed company profitability value per share

Profitability (PA) reflect the listed companies using existing assets operating profit ability. Because of the uncertainty of future earnings, and compared with the past returns, PA and now gains a stronger correlation, so usually through the 
adjusted current income and the cost of capital ratios to measure. Need to pay attention to is: adjusted earnings need meet the following two assumptions:

(1) Allocation is now adjusted to the existing income and the sustainable level of the sustainable level of gold.

(2) Listing Corporation's revenue level remains unchanged in the future.

The calculation formula is as follows:

Profitability $(\mathrm{PA})=$ adjusted earnings $* 1 / \mathrm{R}$

Earnings per share value $=\mathrm{PA} /$ total share capital

Among them, $\mathrm{R}$ represents the capital cost, which is composed of two parts of the capital cost of the listing Corporation by the debt and equity, so it is usually used to replace the $\mathrm{R}$ value with the weighted average capital cost (WACC).

3. The calculation of the growth value of listing Corporation

Under normal circumstances, the growth of the value of the listing Corporation to create the value of the following two variables:

First, the additional capital profitability, additional capital profitability is stronger, the greater the value created by each unit of capital, it is used ROE/R to represent the first variable.

Second, amount of capital used to retrieve franchise earnings, depending on the franchise the pace of development, the growth rate of the ceiling is the cost of capital. So using $\mathrm{G} / \mathrm{R}$ to represent the second variable.

$$
\begin{gathered}
\Gamma \rho \circ \omega \tau \eta \varpi \alpha \lambda v \varepsilon(\Pi \zeta)=\pi \rho \circ \phi \imath \alpha \beta \imath \lambda \imath \tau \psi \varpi \alpha \lambda v \varepsilon(\Pi \mathrm{A}) * \Phi \\
\Phi=(\Pi \zeta / \Pi \mathrm{A})=[(\mathrm{POE}-\Gamma) \cdot \mathrm{P}] /[\mathrm{POE} \cdot(\mathrm{P}-\Gamma)]
\end{gathered}
$$

Growth value per share = growth value/total equity

Where $F$ represents growth factor and roe on behalf of net assets income rate, $G$ stands for the main business income growth rate values greater means the company growth, the greater the value. By the formula is not difficult to see that the F value decided by variable ROE/R and G/R.

4. Function to determine the value of the internal value of the listing Corporation

(1) Basic mathematical model:

The multiple linear regression model is established between the dependent variable and the independent variable.

$$
\begin{gathered}
\mathrm{CV}=\mathrm{aBV}+\mathrm{bP}+\mathrm{cV} \\
P=\frac{W}{p_{1} \times r_{1}+(1-t) \times r_{2} \times p_{2}} \\
v=\frac{W \times[(R O C-G) \times R]}{\left[p_{1} \times r_{1}+(1-t) \times r_{2} \times p_{2}\right] \times[R O C \times(R-G)]}
\end{gathered}
$$

Among them, $\mathrm{CV}$ on behalf of the company value, BV represents the net asset value per share, $\mathrm{P}$ represents profitability per share value, $\mathrm{V}$ per share growth value, $\mathrm{W}$ is adjusted earnings per share, a,b and c represents the weights.
(2) Model coefficient selection:

For a, b and c respectively gives weight, by weight proportion, to determine the value of the company's minimum $\mathrm{CV}_{\min }$ and highest $\mathrm{CV}_{\max }$. The specific formula is as follows:

$$
\begin{aligned}
\mathrm{X}_{\varsigma_{\mu \nu v}} & =1.016 \mathrm{~B} \varsigma+0.283 \Pi+0.105 \varsigma \\
\mathrm{X}_{{ }_{\mu \alpha} \xi} & =1.593 \mathrm{~B} \varsigma+0.503 \Pi+0.203 \varsigma .
\end{aligned}
$$

\section{B. The Intrinsic Value of Listed Companies Analysis Quantitative Evaluation Results}

If the current share price is less than or equal to the minimum value of the company is undervalued, buy the company's stock is expected to obtain excess returns.

If the current stock price falls within the valuation range, note that the stock price is rising, the growth of the company's value has the potential, but the purchase of the company's stock to be cautious.

If the current stock price is greater than or equal to the maximum value, the company's value is overestimated, the company's stock to buy a greater investment risk

\section{AN EMPIRICAL STUDY ON THE EVALUATION OF THE INTRINSIC VALUE OF THE TARGET ENTERPRISE}

\begin{tabular}{|c|c|c|c|}
\hline \multirow{2}{*}{ Index name. } & \multicolumn{3}{|l|}{ Unit: Yuan. } \\
\hline & Carrying amount. & Reset processing. & Adjusted value. \\
\hline Monetary Fund. & $12,228,962,577.48$ & unchanged. & $12,228,962,577.48$ \\
\hline Note receivable. & $40,000,000$ & unchanged. & $40,000,000$ \\
\hline Accounts receivable. & $10,647,292,060.87$ & $\begin{array}{l}\text { Allowance for bad debts } \\
\text { (a) }\end{array}$ & 10434346220 \\
\hline Other receivables. & $101,998,284.08$. & Proportional deduction (b) & 99958318.4. \\
\hline stock. & $10,562,421,502.23$ & Prepare for impairment $(\mathrm{c})$. & 10034300427. \\
\hline Advance payment & $639,341,480.93$. & unchanged. & $639,341,480.93$. \\
\hline Prepaid expenses. & 0. & unchanged. & 0. \\
\hline Total current assets. & $34,220,015,905.59$ & adjustment (d) & 33476909024 \\
\hline Intangible assets. & $580,799,920.36$ & adjustment (e) & 377519948.2 \\
\hline Total assets. & $36,058,281,568.81$ & adjustment (f) . . & 35692694635. \\
\hline Total liabilities. & $21,502,897,700.25$ & unchanged. & $21,502,897,700.25$ \\
\hline Total owners' equity. & $14,555,383,868.56$ & adjustment $(\mathrm{g})$ & 14189796935. \\
\hline Total liabilities and owners' equity. & $36,058,281,568.81$ & adjustment $(\mathrm{h})$ & 35692694635 \\
\hline
\end{tabular}

A. To Assess the Intrinsic Value of Sinovel

1. Calculate net asset value per share (BV)

TABLE I. MARCH 31,2011 SINOVEL EQUITY.

\begin{tabular}{|l|l|}
\hline \multicolumn{2}{|c|}{ March 31 2011. } \\
\hline Total share capital (shares). & $1,005,10$. \\
\hline Tradable shares (shares). & $105,10$. \\
\hline Share of circulation.r & $10.46 \%$. \\
\hline
\end{tabular}

TABLE II. MARCH 312011 NYCCA SHARP WIND POWER BALANCE SHEET AND ADJUSTMENT

Net assets per share $\mathrm{BV}=$ total equity adjusted value divided by the total share capital of $=14189796935.20$ / $1005100000=14.12$ (yuan). 
2. Calculate the value of earnings per share(p)

(1) Calculation of $R$ value

According to the balance sheet of sinovel, the proportion of equity and debt:

P1:P2=14555383868.56 $83019 \quad 21502897700.25=41: 59$, take equity P1 was $41 \%$, debt P2 was $59 \%$. According to the company's annual report, Sinovel headquarters is located in Renmin University of China culture, science and Technology Park of high-tech enterprises, enjoy the preferential tax rate, rate of 2011 Sinovel wind turbine for debt $t=7.5 \%$. provided interest rates take the $\mathrm{R} 2$ = take 3-5 years of interest rate of $6.65 \%$ and more than 5 years rate of $6.8 \%$ of the arithmetic mean value, $\mathrm{R} 2=6.8 \%+6.65 \% / 2=6.73 \% .2010$ end, Sinovel dividend policy is: for every 10 shares sent 10 shares sent 10 yuan (including tax), so the cost of equity capital r1=10\%.

$$
\begin{aligned}
\text { WACC } & =\frac{p_{1} \times r_{1}}{p_{1}+p_{2}}+(1-t) \times r_{2} \times p_{2} \\
& =41 \% \times 10 \%+59 \% \times 6.73 \% \times(1-7.5 \%) \\
& =7.77 \%
\end{aligned}
$$

(2) Calculation of P value

According to the company's annual report, Sinovel 2010 profit 28.56 billion yuan, the growth rate reached more than $50 \%$, assuming that $50 \%$ of the company's growth this year, can be predicted net profit was 42.84 billion yuan 2011 Sinovel wind turbine.

Above, Sinovel's earnings per share value

$$
\begin{aligned}
& \mathrm{P}=\text { adjusted income } * 1 / \mathrm{R} / \text { total share capital } \\
& =4284000000 / 7.77 \% / 1005100000 \\
& =54.64 \text {, the total number of shares (yuan) }
\end{aligned}
$$

3. Calculate the growth value per share $(\mathrm{V})$

TABLE III. SINOVEL NEARLY THREE YEARS THE RATE OF RETURN ON NET ASSETS

\begin{tabular}{|c|c|}
\hline \multicolumn{2}{|c|}{ Sinovel roe } \\
\hline $\mathbf{2 0 0 9 / 1 2 / 3 1}$ & $73.62 \%$ \\
\hline $\mathbf{2 0 1 0 / 6 / 3 0}$ & $39.62 \%$ \\
\hline $\mathbf{2 0 1 0 / 1 2 / 3 1}$ & $59.53 \%$ \\
\hline $\mathbf{2 0 1 1 / 3 / 3 1}$ & $3.01 \%$ \\
\hline
\end{tabular}

ROC to take the average return on net assets = $(73.62 \%+39.62 \%+59.53 \%+3.01 \%) / 4=43.95 \%$

$\mathrm{G}$ take 2010 annual report of the main business revenue growth rate of $\mathrm{R},=48.03 \%$ with a weighted average cost of capital WACC.

Therefore, growth factor

$$
\mathrm{F}=\mathrm{PV} / \mathrm{EPV}
$$

$=[(\mathrm{ROC}-\mathrm{G}) * \mathrm{R}] /[\mathrm{ROC} *(\mathrm{R}-\mathrm{G})]$
$=[(43.95 \%-48.03 \%) \times 7.77 \%] /[43.95 \% \times(7.77 \%-48.03 \%)]$

$=0.018$

Growth value

$$
\begin{aligned}
\mathrm{PV} & =\mathrm{BV} * \mathrm{~F} \\
& =54923076923.08 * 0.018 \\
& =988615384.62 \text { (yuan) }
\end{aligned}
$$

EPS growth value of $\mathrm{V}=\mathrm{PV} /$ Total share capital

$$
\begin{aligned}
& =988615384.62 / 1005100000 \\
& =0.98 \text { yuan (the total number of shares) }
\end{aligned}
$$

4. Sinovel the intrinsic value of the valuation range

$$
\begin{aligned}
\mathrm{CV}_{\min } & =14.12 \times 1.016+0.283 \times 54.64+0.105 \times 0.98 \\
& =29.91 \text { (yuan) } \\
\mathrm{CV}_{\max } & =1.593 \times 14.12+0.503 \times 54.64+0.203 \times 0.98 \\
& =50.08 \text { (yuan) }
\end{aligned}
$$

All the above, the internal value of sinovel valuation range for [29.91, 50.08].

\section{The analysis results of China wind power}

Due to Sinovel intrinsic value range of estimates for the [29.91,50.08], and from Sinovel price charts, we not difficult to see, since listing, Sinovel's share price has been running at a high level, far beyond the intrinsic value of the company. At the same time, the development of wind power by nature a greater impact, industry competition is fierce. Therefore, investment the company has greater risk, the company's stock not worth buying.

\section{B. The Empirical Exploration Results}

Through to the listed companies in China Ruifeng electric empirical analysis, we find that the model of poly the only blue chip valuation results and its stock price correlation degree is high, and Sinovel relatively weak point, but also in the reasonable range. Below we will select 15 equity valuation results are presented in the table with a piece of analysis, As shown in table 4 : 
TABLE IV. TARGET ENTERPRISE STOCK PRICE AND VALUATION INTERVAL COMPARISON TABLE(2011.1-2011.4)

\begin{tabular}{|c|c|c|c|c|}
\hline $\begin{array}{l}\text { The serial } \\
\text { number. }\end{array}$ & $\begin{array}{l}\text { Target } \\
\text { enterprise. }\end{array}$ & Category. & Stock price range. & Valuation interval. \\
\hline 1. & $\begin{array}{l}\text { Sinovel. } \\
\text { (601558) }\end{array}$ & Shares. & {$[65.82,81.37]$} & {$[29.91,50.08]$} \\
\hline 2. & $\begin{array}{l}\text { Societe } \\
\text { Generale } \\
\text { Securities } \\
(601377)\end{array}$ & Shares.. & {$[12.63,19.15]$} & {$[20.80,28.52]$} \\
\hline 3. & $\begin{array}{l}\text { Hang teeth } \\
\text { forward. } \\
(601177)\end{array}$ & Shares., & {$[12.79,17.63]$} & {$[5.17,7.38]$.} \\
\hline 4. & $\begin{array}{l}\text { Lifan cars } \\
(601777)\end{array}$ & Shares. & {$[11.92,14.47]$} & {$[5.41,8.46]$} \\
\hline 5. & $\begin{array}{l}\text { Yonghui } \\
\text { supermarket } \\
(601933)\end{array}$ & $\begin{array}{l}\text { Small cap } \\
\text { stocks. }\end{array}$ & {$[27.07,33.64]$} & {$[9.26,15.19]$.} \\
\hline 6. & $\begin{array}{l}\text { Gehuayouxia } \\
\text { n }(600037)\end{array}$ & $\begin{array}{l}\text { Small cap } \\
\text { stocks.r }\end{array}$ & {$[11.7,13.26]$.} & {$[6.31,7.58]$} \\
\hline 7.. & $\begin{array}{l}\text { Talph } \\
\text { pharmaceutic } \\
\text { al }(600222)\end{array}$ & $\begin{array}{l}\text { Small cap } \\
\text { stocks.r }\end{array}$ & {$[6.28,7.61]$} & {$[7.80,10.37]$.} \\
\hline 8. & $\begin{array}{l}\text { Taiyuan } \\
\text { Heavy } \\
\text { Industries } \\
(600169) .\end{array}$ & $\begin{array}{l}\text { Small cap } \\
\text { stocks. }\end{array}$ & {$[21.32,27.49]$} & {$[6.90,11.04]$.} \\
\hline 9. & $\begin{array}{l}\text { Weiyuan } \\
\text { biochemistry } \\
(600803)\end{array}$ & $\begin{array}{l}\text { Small cap } \\
\text { stocks.r }\end{array}$ & {$[12.09,14.95]$} & {$[20.4,23.61]$.} \\
\hline 10. & $\begin{array}{l}\text { Hua Fang } \\
\text { textile } \\
(600273)\end{array}$ & $\begin{array}{l}\text { Small cap } \\
\text { stocks. }\end{array}$ & {$[13.36,14.91]$} & {$[14.10,17.97]$} \\
\hline 11. & $\begin{array}{l}\text { Shanghai } \\
\text { Pudong } \\
\text { Development } \\
\text { Bank } \\
(600000)\end{array}$ & $\begin{array}{l}\text { blue-chip } \\
\text { share. }\end{array}$ & {$[12.61,14.57]$} & {$[13.05,26.80]$} \\
\hline 12 & $\begin{array}{l}\text { Huaxia Bank } \\
(600015)\end{array}$ & $\begin{array}{l}\text { blue-chip } \\
\text { share. }\end{array}$ & {$[11.13,13.76]$} & {$[7.90,15.60]$} \\
\hline 13 . & $\begin{array}{l}\text { China Ping } \\
(601318)\end{array}$ & $\begin{array}{l}\text { blue-chip } \\
\text { share. }\end{array}$ & {$[48.50,56.91]$} & {$[26.40,50.07]$} \\
\hline 14. & $\begin{array}{l}\text { Chinese } \\
\text { architecture } \\
(601668)\end{array}$ & $\begin{array}{l}\text { blue-chip } \\
\text { share. }\end{array}$ & {$[3.48,4.08]$.} & {$[5.31,8.02]$} \\
\hline 15. & $\begin{array}{l}\text { Sany } \\
(600031)\end{array}$ & $\begin{array}{l}\text { blue-chip } \\
\text { share. }\end{array}$ & {$[19.16,28.89]$} & {$[15.60,26.12]$} \\
\hline
\end{tabular}

1. Correlation degree analysis

Can be seen from the chart, the valuation model of the valuation results of blue-chip shares with correlation degree is high, the valuation results of small-cap stocks and shares in correlation with its share price almost, but also in a reasonable range, this may be related to the stock market speculative atmosphere is strong, share price volatility is a lot to do.

\section{Differential analysis}

In table 4, despite deviation share price and value, but the difference is not far. Below we in blue-chip stocks, for example, using SPSS software to analyze the difference of the valuation and stock price:

(1) the minimum stock price and the minimum valuation:

TABLE V. LOWEST PRICE AND MINIMUM VALUE OF 1

\begin{tabular}{|c|c|c|c|c|}
\hline & One-Sample Statistics. \\
\hline & N.r & Mean. & $\begin{array}{c}\text { Std. } \\
\text { Deviation. }\end{array}$ & $\begin{array}{c}\text { Std. Error } \\
\text { Mean. }\end{array}$ \\
\hline $\begin{array}{c}\text { Minimum stock price } \\
\text { and minimum valuation } \\
\text { difference. }\end{array}$ & $14 .$. & $2.0507 .$. & $6.1053 .$. & 1.63171. \\
\hline
\end{tabular}

TABLE VI. MINIMUM STOCK PRICE AND MINIMUM VALUATION TEST 2

\begin{tabular}{|c|c|c|c|c|c|c|}
\hline & One-Sample Test. \\
\hline Test Value $=0$. & T.r & df. & $\begin{array}{c}\text { Sig. } \\
\text { (2-tailed).. }\end{array}$ & $\begin{array}{c}\text { Mean } \\
\text { Difference. }\end{array}$ & \multicolumn{2}{|c|}{$\begin{array}{c}95 \% \text { Confidence Interval of } \\
\text { the Difference Lower Upper.. }\end{array}$} \\
\hline $\begin{array}{c}\text { Minimum stock } \\
\text { price and } \\
\text { minimum } \\
\text { valuation } \\
\text { difference. }\end{array}$ & 1.3. & 13. & $0.231 .$. & $2.05071 .$. & -1.4744. & 5.5758. \\
\hline
\end{tabular}

Chip can be seen from the table, although the valuation industry value and stock price average deviation, deviation and standard deviation, but the differences in the two groups of data within a reasonable range. This indicates that the model evaluation results accord with the reality of the value of the company, has its rationality. At the same time also suggests that the net asset value, profitability and growth value investors value indicators of concern

\section{CONCLUSION}

Accurate assessment of the intrinsic value of a listed company is a very difficult thing to do, by using of the constructed model to evaluate the listed company's intrinsic value will inevitably be biased. Through the above empirical exploration, we found that the model constructed in this paper of A-share listed companies in Shanghai Stock Exchange in the assessment of the value of the results conform to reality, certain rationality. It was also found that, relatively high degree of the model on the blue chips assessment results and its stock price Association, and the association of new shares and small cap stocks assessment results and its stock price weak point. This may and shares and small cap stocks in the market speculation atmosphere, the volatility of the stock price is relatively large relationship.

\section{REFERENCES}

[1] Benjamin Graham, Dodd David. Securities analysis [M], Hainan publishing, 1999

[2] Tom Copeland, Tim Khloe. Value evaluation [M], China Encyclopedia press, 2001

[3] Bai Na, Gu Weijun. Empirical analysis on the stock exchange rate of Shanghai Composite Index [J]. Journal of Zhejiang University, 2002 (9)

[4] Geng Zhimin. Institutional investors of China [J] Journal of Renmin University of China, 2009 (11)

[5] Fu Ziheng. Financial indicators in the eyes of securities analysts [J]. Journal of Shanghai University of Finance and Economics, 2006 (11)

[6] Liu Yesong, Yang Yi. Literature review on the evaluation model of intrinsic value of stock [J]. modern economic research, 2003

[7] Fu Yi, Zhang Ping. Evaluation of company value and analysis of securities investment [M], China financial and Economic Publishing House, 2001

[8] Bradford Canal, Zhang Zhiqiang, et al., the company valuation, Huaxia publishing house, 2001

[9] Li Jianjun. Enterprise value assessment methods and practical analysis of [J]. accounting communication 2008

[10] William H. Beaver Perstective on Recent Capital Market Research, The Accounting Review,2002 V01.77, No 2. 